\title{
Water Quality and Pollution Index of Kreo and Garang River from Jatibarang Landfill in Semarang City
}

\author{
Wardani Adi Saputra*, Onny Setiani, Mursid Rahardjo \\ Department of Environmental Health, Faculty of Public Health, Diponegoro University, Semarang, \\ Indonesia
}

\begin{abstract}
Jatibarang landfill is the final waste disposal site in Semarang that is located near the Kreo River. The existence of landfill near watershed are related to environmental problems caused by landfill leachate that is not managed properly and cause a decrease in water quality. The purpose of this study was to determine the water quality and pollution index of Kreo and Garang River as the biggest river in Semarang. This research was a descriptive study with an observational approach, consisted of 8 sampling sites and using the pollution index method. The results of this study show that the highest BOD concentration is 36.95 and the lowest is $7 \mathrm{mg} / \mathrm{l}$, the highest COD concentration is 1575 and the lowest is $19 \mathrm{mg} / \mathrm{l}$ and the highest DO concentration is 7.75 and the lowest $0.14 \mathrm{mg} / \mathrm{l}$. Based on the pollution index analysis, it shows that the highest Pollution index is 7.38, which means that Kreo and Garang River flow is categorized as polluted and the lowest pollution index is 2.32 classified as moderate polluted. In conclusion, the water quality is decreased due to various activities nearby that marked with moderately polluted and polluted resulted by water quality and pollution index assessment.
\end{abstract}

Keywords. Water Quality; Pollution Index; River; Landfill.

\section{Introduction}

Water is a vital natural resource and is needed by all living things, animals and humans. Therefore we need protection to obtain better water quality and sustainability from these natural resources. One source of water that is often used is river water. River water produced from upstream often has better water quality than downstream. This is because the flow will flow towards the downstream for will be polluted by various sources of pollutant activities across rivers, industry, animal husbandry, agriculture, landfill that marked by the increase of BOD and COD concentration and decrease of DO concentration[1].

\footnotetext{
* Corresponding author: wardaniadisaputra130@gmail.com
} 
The city of Semarang as a metropolis is marked by the development of various sectors and rapid population growth so that it results in an increase in the volume of waste in the Jatibarang landfill as a final waste disposal site in the city of Semarang. The composition of waste in Jatibarang Landfill is $77.7 \%$ organic waste, $14.19 \%$ plastics, 5.31 mixed paper and $1.36 \%$ others.[2] Based on several studies conducted by Sudarwin (2008), Astin Kurniawati (2015), Yeremia Susanti (2016), and Tito Hasna Saniy (2017), it is stated that the Jatibarang landfill already has a Wastewater Treatment Plant for treating leachate waste. However, the implementation was less effective because there were still problems related to the physical condition of the aged leachate tank so it was prone to leakage and the method used was biologically method, so that it had not been able to reduce the content of the organic material in it. This allows a decrease in water quality because Jatibarang landfill activity will always undergo a process of decomposition with the result of a liquid or gas called leachate[3-6].

Leachate will affect the waters because it contains inorganic, organic and heavy metal compounds so that if it is not treated correctly, it will potentially cause health problems for humans and the environment when reaching land, groundwater and surface water[7]. In identifying contamination in waters, water quality testing is needed at several stations starting from the Kreo and Garang Rivers, which consist of biological oxygen demand (BOD) parameters, chemical oxygen demand (COD) and dissolved oxygen (DO).

Based on observations that have been made in Jatibarang landfill Leachate tanks, the colors and odors do not meet the requirements, because they are blackish-brown and have a pungent odor. Whereas based on the results of tests conducted on leachate in Jatibarang landfill, the results for the concentration of biological oxygen demand (BOD) were 36.89 $\mathrm{mg} / \mathrm{l}$, chemical oxygen demand (COD) was $1912 \mathrm{mg} / \mathrm{l}$ and Dissolved Oxygen (DO) in the amount of $0.08 \mathrm{mg} / \mathrm{l}$ that does not meet the quality standards set in the Minister of Environment Regulation No. 5/2014 concerning Wastewater Quality Standards.

From the background described above and considering the function of water from the river that is still used by the surrounding community for the daily needs of the community and the main raw material in the provision of drinking water for the community in the city of Semarang through PDAM Tirta Moedal. The problem formulation of this research is how the distribution of water quality and pollution index of Kreo and Garang river from the Jatibarang landfill. The purpose of this study was to determine the water quality and pollution index of Kreo and Garang River from Jatibarang landfill Semarang.

\section{Study Method}

\subsection{Study Site}

This research was conducted in April 2020 in Semarang City, Central Java, Indonesia, from the upstream, middle and downstream parts, namely the Kreo River, the Kripik River, the Garang River and Java Sea which has a length of about $12.7 \mathrm{Km}$ by dividing into 8 stations to see the effect of various activities on water quality. The following is a description of the water sampling station

a. Station 1, located at Jatibarang TPA outlet with coordinates $07^{\circ} 02$ ' 84 ' $S$ and $110^{\circ} 36^{\prime} 00^{\prime \prime} \mathrm{E}$

b. Station 2, located on the Kreo River flow with coordinates $07^{\circ} 01^{\prime} 74^{\prime}$ 'S and $110^{\circ} 38^{\prime} 73$ ' $E$

c. Station 3, located on the Kripik River flow with coordinate $07^{\circ} 01^{\prime} 79^{\prime}$ 'S and $110^{\circ} 38^{\prime} 75^{\prime}$ ' E

d. Station 4, located on the Kreo River near the Suharto monument with coordinates $07^{\circ}$ 02 '32' 'S and $110^{\circ} 37^{\prime} 83^{\prime \prime}$ 'E. 
e. Station 5, located on the flow of the Garang River near the Soeharto Monument with coordinates $07^{\circ} 02^{\prime} 34^{\prime \prime} \mathrm{S}$ and $110^{\circ} 37^{\prime} 86^{\prime}$ 'E

f. Station 6, located on the mainstream of the Garang River with coordinate $07^{\circ} 00^{\prime} 32^{\prime}$ 'S and $110^{\circ} 39^{\prime} 62^{\prime \prime} \mathrm{E}$

g. Station 7, located on the river Garang near PDAM Tirta Moedal Semarang with coordinates $07^{\circ} 00^{\prime} 12^{\prime \prime} \mathrm{S}$ and $110^{\circ} 40^{\prime} 11^{\prime \prime} \mathrm{E}$

h. Station 8 , located on the estuary of the Garang River (Java Sea) with coordinates 06 ${ }^{\circ} 94^{\prime} 86^{\prime \prime}$ 'S and $110^{\circ} 40^{\prime} 21^{\prime \prime} \mathrm{E}$.

\subsection{Research Method}

This study used descriptive study with an observational approach, that is useful in describing a phenomenon the quality of river water that is BOD, COD, DO and pollution index, while the research with grab sampling techniques. Grab sampling is a momentary sampling technique that shows the characteristics of water at that time using sampler tools according to SNI 6989.59: 2008.

Table 1. Parameters, units and water testing methods

\begin{tabular}{|c|c|c|c|}
\hline Parameters & Units & Method & Information \\
\hline Temperature & ${ }^{\circ} \mathrm{C}$ & Thermometer & Laboratory Testing \\
\hline $\mathrm{pH}$ & - & Ph Meter & Field Testing \\
\hline $\mathrm{BOD}$ & $\mathrm{Mg} / \mathrm{L}$ & BOD Meter Method & Laboratory Testing \\
\hline $\mathrm{COD}$ & $\mathrm{Mg} / \mathrm{L}$ & Lab. Vis.Spectro Method & Laboratory Testing \\
\hline
\end{tabular}

\subsection{Data Analysis}

Analysis of water quality data in this study used the univariate method and the Pollution Index (IP). Pollution Index (IP) is a tool to assess water quality by showing the level of pollution to water quality standards (BMA) of the five parameters of water quality that have been determined and tested previously, namely the parameters of Temperature, $\mathrm{pH}, \mathrm{BOD}$, COD and DO. This is in accordance with river water requirements listed in the Ministry of Environment's Degree No. 115/2003 Regarding the Guidelines for Determination of Water Quality Status. The following formula is used to calculate the pollution index (IP).

Information

$$
\frac{\sqrt{(\mathrm{Ci} / \mathrm{Lij}) \mathrm{m}^{2}+\left(\mathrm{Ci} / \mathrm{lij}_{\mathrm{ij}}\right) \mathrm{r}^{2}}}{2}
$$

$\mathrm{PIj}$

$\mathrm{Ci}$

: Water pollution index $(\mathrm{J})$

Lij

: Concentration produced from laboratory testing parameter

(Ci / Lij)r

: Concentration of quality standards of the parameters listed on the water allotment quality standard $(\mathrm{J})$

$(\mathrm{Ci} / \mathrm{Lij})_{\mathrm{m}} \quad$ : maximum $\mathrm{Ci} / \mathrm{Lij}$ value.

After calculating for the analysis of the pollution index (IP) method, then grouping the calculations into the appropriate category in the pollutant index criteria. The following table is used in estimating the pollution index (IP) criteria developed by Canter (1977). 
Table 2. Pollution Index Criteria $[8,9]$

\begin{tabular}{|c|c|c|}
\hline No & Pollution Index Value (IP) & Pollution Index Criteria (IP) \\
\hline 1 & $0-1,0$ & Good Water Quality \\
\hline 2 & $1,1-5,0$ & Moderately polluted \\
\hline 3 & $5,1-10,0$ & Polluted \\
\hline 4 & $>10,00$ & Extremely polluted \\
\hline
\end{tabular}

\section{RESULTS AND DISCUSSION}

\subsection{Water Quality Analysis}

Water quality analysis was carried out to determine the suitability of the waters with their designation to prevent water quality degradation in the waters by comparing with the quality standards contained in Government Regulation No. 82/2001 concerning the management quality and control of water pollution. The following are the results of the water quality analysis of each parameter.

\subsubsection{Temperature}

The results of measurements of the temperature parameters at stations 1 to station 8 range from $28.5-34.4^{\circ} \mathrm{C}$ so that each observation point shows that overall meet the quality standards that have been determined based on Government Regulation No. 82/2001 on the management of water quality and control over water pollution, the calculated range (mean +3) from natural temperature.

Table 3. Results of Temperature Measurement at Water Sample Points

\begin{tabular}{|c|c|c|c|}
\hline Sample Station & Time & Temperature & Category \\
\hline Station 1 & 09.25 & $34.4^{\circ} \mathrm{C}$ & Non-Eligible (Very Warm) \\
\hline Station 2 & 08.45 & $28.7^{\circ} \mathrm{C}$ & Eligible (Warm) \\
\hline Station 3 & 08.50 & $28.8^{\circ} \mathrm{C}$ & Eligible (Warm) \\
\hline Station 4 & 10.30 & $31.6^{\circ} \mathrm{C}$ & Non-Eligible (Very Warm) \\
\hline Station 5 & 10.20 & $31.0^{\circ} \mathrm{C}$ & Non-Eligible (Very Warm) \\
\hline Station 6 & 09.17 & $28.6^{\circ} \mathrm{C}$ & Eligible (Warm) \\
\hline Station 7 & 09.27 & $28.5^{\circ} \mathrm{C}$ & Eligible (Warm) \\
\hline Station 8 & 09.59 & $30.0^{\circ} \mathrm{C}$ & Eligible (Warm) \\
\hline
\end{tabular}

The increase of temperature in some sites of these stations especially station 1 is due to the morphology of the open waters, which has an extensive river body with a little overgrown by trees so that the sunlight can directly penetrate the waters and the sampling is done during the day. Besides the rise in temperature in the waters is also closely related to the level of solubility of gases that are in the waters such as $\mathrm{CO}_{2}, \mathrm{~N}_{2}, \mathrm{CH}_{4}$ especially $\mathrm{O}_{2}$ which will decrease, due to an acceleration of respiration by organisms so that the process of degradation of organic matter in the water becomes faster. However, there is a difference at station 7 due to differences in water characteristics[10]. 


\subsection{2 $\mathrm{pH}$}

The measurement results of the $\mathrm{pH}$ parameters at stations 1 to station 8 range from $6-8$ so that each observation point shows that there is no large difference and meets the quality standards that have been determined based on Government Regulation No. 82/2001 on the management of water quality and control over water pollution is 6-9.

Table 4. Results of $\mathrm{pH}$ Measurement at Water Sample Points

\begin{tabular}{|c|c|c|c|}
\hline Sample Station & Time & Ph & Category \\
\hline Station 1 & 09.27 & 6 & Eligible \\
\hline Station 2 & 08.47 & 7 & Eligible \\
\hline Station 3 & 08.52 & 7 & Eligible \\
\hline Station 4 & 10.32 & 7 & Eligible \\
\hline Station 5 & 10.22 & 7 & Eligible \\
\hline Station 6 & 09.19 & 8 & Eligible \\
\hline Station 7 & 09.29 & 8 & Eligible \\
\hline Station 8 & 10.01 & 8 & Eligible \\
\hline
\end{tabular}

Changes in the acidity of the water, both acidic and basic, are influenced by the condition of the gases in the waters such as $\mathrm{CO}_{2}$ and the decomposition process of organic matter in the underwater. According to Effendi (2003), it is stated that most aquatic organisms pH ranges between $7-7.5$ and are susceptible to changes in $\mathrm{pH}$. If the waters are too acidic, especially at station 1 it will endanger aquatic organisms because it can interfere with metabolism, respiration of aquatic organisms as well as the diversity of organisms in decreased waters. Unlike if it is too alkaline especially station 6,7 and 8, organisms will have higher ammonia content in their bodies, which damages the respiratory tissue in fish namely the gills. This is because each aquatic organism has a $\mathrm{pH}$ value with a different tolerance range[11].

\subsubsection{Biological Oxygen Demand (BOD)}

The results of measurements of BOD parameters at stations 1 to station 8 range from 7.0 $36.95 \mathrm{mg} / 1$ so that each observation point shows that overall does not meet the quality standards that have been determined based on Government Regulation No. 82/2001 on the management of water quality and control over water pollution is $3.0 \mathrm{mg} / \mathrm{l}$.

Table 5. Results of BOD Measurement at Water Sample Points

\begin{tabular}{|c|c|c|c|}
\hline Sample Station & Time & BOD & Category \\
\hline Station 1 & 09.25 & $36.95 \mathrm{mg} / 1$ & Polluted \\
\hline Station 2 & 08.45 & $17.05 \mathrm{mg} / 1$ & Polluted \\
\hline Station 3 & 08.50 & $7.02 \mathrm{mg} / 1$ & Polluted \\
\hline Station 4 & 10.30 & $7.03 \mathrm{mg} / 1$ & Polluted \\
\hline Station 5 & 10.20 & $7.05 \mathrm{mg} / 1$ & Polluted \\
\hline Station 6 & 09.17 & $7.06 \mathrm{mg} / 1$ & Polluted \\
\hline Station 7 & 09.27 & $7.04 \mathrm{mg} / 1$ & Polluted \\
\hline Station 8 & 09.59 & $7.00 \mathrm{mg} / 1$ & Polluted \\
\hline
\end{tabular}


The highest concentration at Station 1 is due to the contribution of a large activity to the waters the Jatibarang Landfill, which produces leachate that will be flowed into the Kreo River. This incident contributed to the decline in water quality which is characterized by high concentrations of BOD at this station because leachate contains many substances such as proteins, carbohydrates and fats that are often used by microorganisms as a source of nutrients to produce energy which is then used in the process of degradation of organic matter in the waters[12]. In addition, there was an increase in concentration in several stations because it was influenced by contributions from other activities, namely livestock, agriculture, industry and especially settlements found in the Kreo, Kripik and Garang Rivers from household water discharges such as washing water, urine, human waste (feces) and waste dumped directly into the water (disposal) also contribute in increasing the BOD concentration. However, there is a difference at station 8 with the lowest concentration because at this station there is no large activity so the resulting BOD concentration is not as big as Station 1.

\subsubsection{Chemical Oxygen Demand (COD)}

The results of measurements of COD parameters at stations 1 to station 8 range from 19 $1575 \mathrm{mg} / \mathrm{l}$ so that each observation point shows that overall does not meet the quality standards that have been determined based on Government Regulation No. 82/2001 on the management of water quality and control over water pollution is $25 \mathrm{mg} / \mathrm{l}$.

Table 6. Results of COD Measurement at Water Sample Points

\begin{tabular}{|c|c|c|c|}
\hline Sample Station & Time & \multicolumn{1}{|c|}{ COD } & Category \\
\hline Station 1 & 09.25 & $1575 \mathrm{mg} / 1$ & Polluted \\
\hline Station 2 & 08.45 & $122 \mathrm{mg} / 1$ & Polluted \\
\hline Station 3 & 08.50 & $60 \mathrm{mg} / 1$ & Polluted \\
\hline Station 4 & 10.30 & $95 \mathrm{mg} / 1$ & Polluted \\
\hline Station 5 & 10.20 & $48 \mathrm{mg} / 1$ & Polluted \\
\hline Station 6 & 09.17 & $58 \mathrm{mg} / 1$ & Polluted \\
\hline Station 7 & 09.27 & $95 \mathrm{mg} / 1$ & Polluted \\
\hline Station 8 & 09.59 & $19 \mathrm{mg} / 1$ & Non Polluted \\
\hline
\end{tabular}

The highest concentration at Station 1 is caused by the contribution of relatively high activity, namely the Jatibarang landfill which will produce pollutant sources in the form of leachate, but the sewage flowed to the Kreo River has not been optimally treated even though the Jatibarang landfill already has a wastewater treatment plant. In addition, the landfill in Indonesia only focuses on processing waste. In fact, the landfill will produce leachate, which has more impact than waste, so that the processing unit in the form of WWTP is still as it is the effluent from the processing unit is always above the quality standard set by the government.

This is because leachate is classified as a type of waste that is difficult to process differently than other wastes and management in the Jatibarang Landfill still uses biological methods so that it has not been able to set aside organic materials contained in leachate such as protein, carbohydrates and fats which will be used by microorganisms as source nutrition to produce energy for the degradation process of all organic materials, either biodegradable or non-biodegradable contained in the waters[13]. However, there is a difference at station 8 with the lowest COD concentration, because at this station the characteristics of seawater 
which have a salinity of $3.4 \%$ so that it becomes a dispersing medium that has strong ions. Consequently sea water can damage the stability of the hydrogen bond between the waste and water. This causes the distribution of COD concentrations in the river flow towards the sea will be better because it has the ability to separate[2].

\subsubsection{Dissolved Oxygen (DO)}

The results of measurements of temperature DO at station 1 to station 8 range from 0.14 $7.75 \mathrm{mg} / \mathrm{l}$ so that each observation point shows that overall still meets the specified quality standards except station 1 based on Government Regulation No. 82/2001 on the management of water quality and control over water pollution, which is a minimum of $4 \mathrm{mg} / \mathrm{l}$.

Table 7. Results of DO Measurement at Water Sample Points

\begin{tabular}{|c|c|c|c|}
\hline Sample station & Time & DO & Category \\
\hline Station 1 & $09.25 \mathrm{am}$ & $0.14 \mathrm{mg} / 1$ & Non Eligible (Very Low) \\
\hline Station 2 & $08.45 \mathrm{am}$ & $7.39 \mathrm{mg} / 1$ & Eligible \\
\hline Station 3 & $08.50 \mathrm{am}$ & $7.39 \mathrm{mg} / 1$ & Eligible \\
\hline Station 4 & $10.30 \mathrm{am}$ & $7.42 \mathrm{mg} / 1$ & Eligible \\
\hline Station 5 & $10.20 \mathrm{am}$ & $7.75 \mathrm{mg} / 1$ & Eligible \\
\hline Station 6 & $09.17 \mathrm{am}$ & $7.28 \mathrm{mg} / 1$ & Eligible \\
\hline Station 7 & $09.27 \mathrm{am}$ & $6.91 \mathrm{mg} / 1$ & Eligible \\
\hline Station 8 & $09.59 \mathrm{am}$ & $7.19 \mathrm{mg} / 1$ & Eligible \\
\hline
\end{tabular}

The low concentration of station 1 influences the activity of the Jatibarang landfill so that dissolved oxygen contained in these waters is used by microorganisms to degrade organic waste in the form of leachate water resulting in high concentrations of BOD and COD in water. Besides, high temperature also contributes to causing biological activity in aquatic organisms experiencing an increase in the speed of metabolism and respiration of aquatic organisms so that it gives an effect on increasing the amount of oxygen consumption as much as 2-3 times so that the concentration of dissolved oxygen in the waters decreases[14]. Also, at this station the level of water brightness tends to be dark so that it interferes with the penetration of light entering the liquid, which causes the process of photosynthesis in the water to be disrupted as a source of oxygen in the water[15]. the condition of the low concentration of dissolved oxygen in the waters can cause aquatic organisms that have water disturbed and even die because of insufficient oxygen demand[16]. However, the increase in concentration at several stations such as at station 5 which has the highest DO concentration is due to the influence of river characteristics that show relatively uneasy flow patterns so that turbulence will occur in the waters, which results in the process of reaeration of air into the water so that the oxygen content in the waters increases[17].

\subsection{Pollution Index Analysis (PI)}

The determination of water quality status in the waters of the Kreo and Garang rivers is based on the pollution index (PI) method, which is around 2.45 to 7.54 . The pollution index values for each station are presented as follows. 
Table 8. Results of water pollution index (PI)

\begin{tabular}{|c|c|c|}
\hline Sample station & Pollution index & Category \\
\hline Station 1 & 7.54 & Polluted \\
\hline Station 2 & 3.87 & Moderately Polluted \\
\hline Station 3 & 2.46 & Moderately Polluted \\
\hline Station 4 & 3.22 & Moderately Polluted \\
\hline Station 5 & 2.45 & Moderately Polluted \\
\hline Station 6 & 2.48 & Moderately Polluted \\
\hline Station 7 & 3.17 & Moderately Polluted \\
\hline Station 8 & 2.32 & \\
\hline
\end{tabular}

Based on the calculation of the pollutant index (IP) in table 7, it can be seen that there has been a decrease in water quality by showing that all stations are in a moderately polluted and polluted category based on Ministry of Environment's Degree No. 115/2003 Regarding the Guidelines for Determination of Water Quality Standard. The highest pollution index results at Station 1 because it affects the Jatibarang landfill activity as a Final Disposal site of all Semarang City, which contributes to water pollution because the Jatibarang landfill waste treatment is not managed properly. This condition makes DO concentrations low because it is used by microorganisms in decomposing organic matter, which causes an increase in BOD and COD concentrations in the waters as well as a reduced ability to cope with pollution commonly called self-purification. It is different from other stations that are getting downstream because pollution is decreasing, like station 8 . This is because this location does not have a large source of pollution that contributes to pollution and at this station is supported by increased DO contribution overcoming pollution, which is commonly called self-purification[18].

\subsection{Water Pollution Control Strategy}

Water pollution control strategies are efforts to prevent, control and restore water pollution so that the quality of river water is in accordance with its designation.

a. Improve the inventory and identification of water pollution sources

Inventory of sources of pollution is carried out to determine the causes of deterioration in water quality by characterizing the flow of pollution in the environment, while identification is carried out to identify and classify the types of pollutants, sources, locations and impacts.

b. Improve the effectiveness of WWTP management at Jatibarang Landfill

The improvement of waste management is carried out by increasing the effectiveness of the management of IPAL at the Jatibarang TPA through methods or technology that can be used so that the waste disposed of into the Kreo River does not exceed the quality standards set by the government.

c. Increased community participation

Increased community participation in saving, preserving and protecting the environment prevents a decrease in water quality. 
d. Increased supervision of waste disposal

Supervision of businesses that dispose of waste into waters around river flows can be carried out by ensuring the implementation of the requirements stated in the environmental permit for disposal of wastewater into rivers and the technical requirements for water pollution control listed in UKL / UPL. The results of supervision can be used as a reference in law enforcement for business actors who violate the regulations that have been established to deter the perpetrator if the waste disposed of exceeds the quality standards set by the government.

e. Improved coordination to monitoring water quality

Improved coordination in routine water quality monitoring through measurement of water quality parameters consist physical, chemical and biological in the Kreo River, Kripik River and Garang River, then the results of water quality monitoring are reported to be followed up. 


\section{Pollution Index Map}
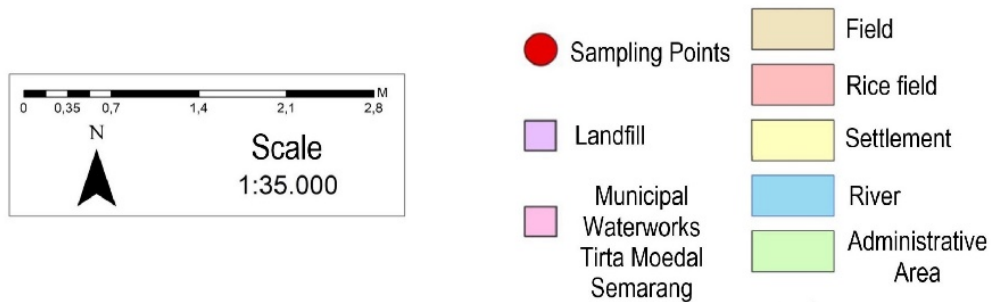

$110^{\circ} 22^{\prime} 30^{\prime \prime} \mathrm{E}$ $10^{\circ} 24^{\prime O} \mathrm{O}^{\prime \prime} \mathrm{E}$ $110^{\circ} 25^{\circ} 30^{\mathrm{m}} \mathrm{E}$

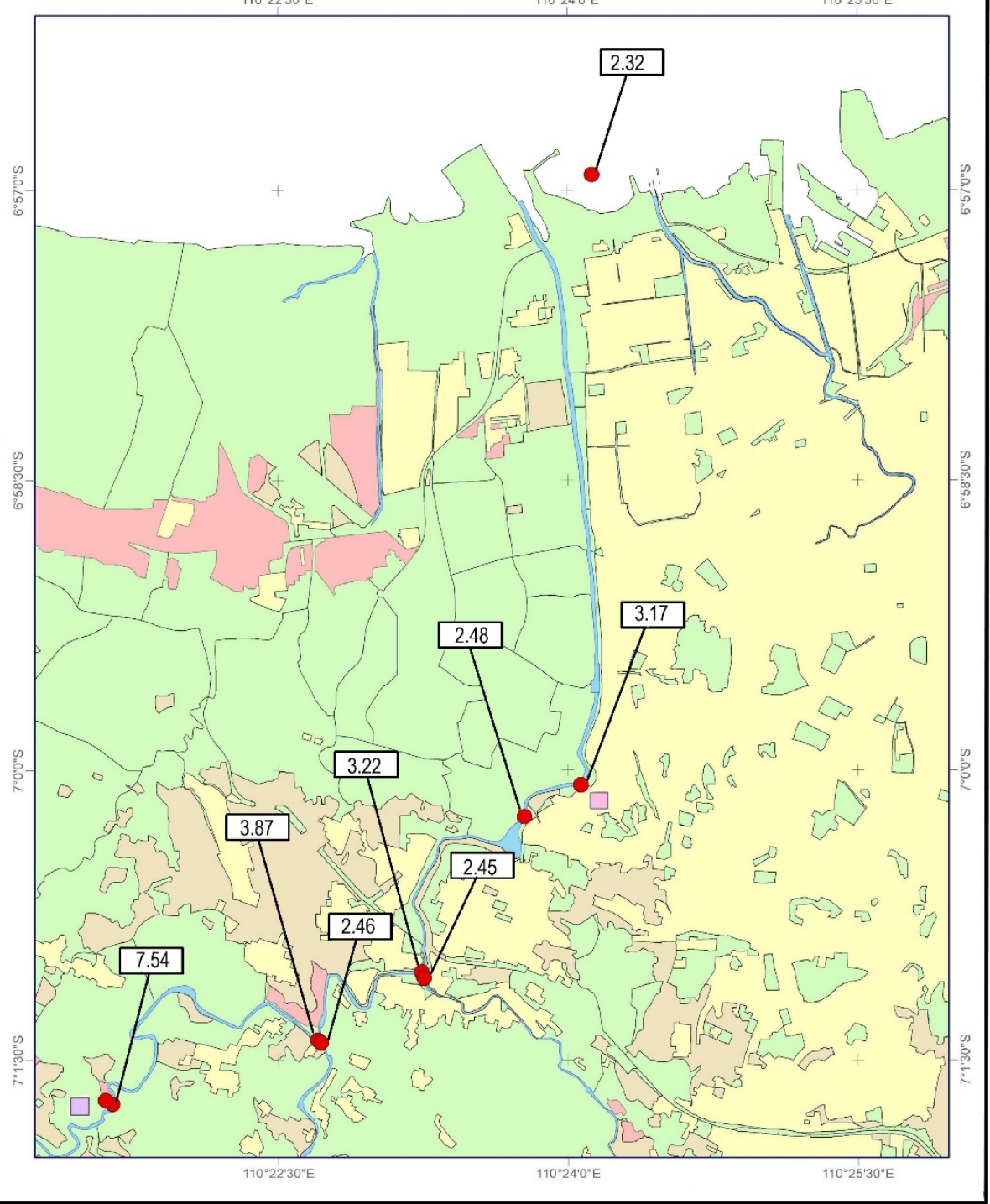

Fig. 1. Map of A Pollution Index Map 


\section{CONCLUSION}

Water quality from upstream to downstream has decreased the quality of river water by showing the results of the highest water pollution index of 7.38 found in the Jatibarang landfill outlet with moderately polluted criteria and the lowest at 2.32 found at the estuary of the Garang River (Java Sea) with moderately polluted criteria. Based on the regulation of the Ministry of Environment's Degree No. 115/2003 Regarding the Guidelines for Determination of Water Quality Status. The fluctuating pollutant index results at this station are caused to be influenced by contributions from low or high concentrations of pollutants such as BOD, COD and DO that exceed the quality standards specified in Government Regulation No. 82 of 2001 concerning Management of Water Quality and Control of Water Pollution. This shows that the distribution of water quality will decrease, if the station gets closer to pollutant activity, namely Jatibarang landfill with the highest concentration of pollutant index at station 1 and the lowest at station 8 .

\section{REFERENCE}

1. Hamakonda UA, Suharto B, Susanawati LD, Analysis of Water Quality and Water Pollution Burden in Sub Basin Boentuka, South Central Timor Regency, J Teknol Pertan Andalas, 23:56 (2019)

2. Budihardjo MA, Wahyuningrum IFS, Recovery Practice of Unsorted Solid Waste: From Landfill towards Economic Benefits in Semarang, Indonesia, MATEC Web Conf 159:04 (2018)

3. Sudarwin, Spatial analysis of heavy metal pollution ( $\mathrm{pb}$ and $\mathrm{cd}$ ) in river flow sediments from Jatibarang Landfill. Diponegoro University, (2008)

4. Kurniawati A, Nugroho AS, Kaswinarni F, The Impact of Landfill Leachate Jatibarang Towards the Diversity and Abundance of Plankton in the Waters of Kreo River Semarang City., 708-713 (2015)

5. Susanto Y, Planning of Jatibarang Final Processing Site, Semarang City with Sanitary Landfill System, Soegijapranata Catholic University (2016)

6. Saniy T, Leachate Processing Using Coagulation Flocculation Method With Biocoagulation Chitosan From Shrimp Shell Waste and Ozonation Method (Case Study: Leachate TPA Jatibarang, Semarang City), 6:1-11(2017)

7. Baderna D, Caloni F, Benfenati E, Investigating landfill leachate toxicity in vitro: A review of cell models and endpoints, Environ Int 122:21-30 (2019)

8. Barokah GR, Ariyani F, Siregar TH, Comparison of Storet and Pollution Index Method to Assess the Environmental Pollution Status: A Case Study from Lampung Bay, Indonesia, Squalen Bull Mar Fish Postharvest Biotechnol 12:67 (2017)

9. Effendi H, Romanto, Wardiatno Y, Water Quality Status of Ciambulawung River, Banten Province, Based on Pollution Index and NSF-WQI, Procedia Environ Sci 24:228-237 (2015)

10. Khairul, Study of aquatic physics and chemistry factors on aquatic biota in the Belawan river ecosystem, UNA 3:1132-1140 (2017)

11. Yulis PAR, Analysis of Mercury $(\mathrm{Hg})$ and $(\mathrm{pH})$ Metals in Kuantan River Water Impact of Gold Without Storage Permit (Crates), Orbital J Pendidik Kim 2:28-36 (2018)

12. Paramita $P$, Shovitri M, Kuswytasari ND, Biodegradation of market organic waste by using natural microorganisms in septic tanks, J Sains Dan Seni Its 1:23-26 (2012)

13. Rezagama A, Hadiwidodo M, Purwono P, Ramadhani NF, Yustika M, The removal of organic waste from landfill leachate rarely uses chemical coagulation and flocculation, 37:78 (2016) 
14. Iha L, Ramli M, Ode L, Response of Jewel Damsel (Plectroglyphidodon lacrymatus) Towards Temperature Rise, 2:45-53 (2017)

15. Irawati N, Adiwilagab EM, Pratiwi NTM, Phytoplankton Primary Productivity Relationship To The Availability Of Nutrient Element And Light Intercity In The Water Of Kendary Bay at Southeast Sulawesi, J Biol Trop 13:197-208 (2013)

16. Hamuna B, Tanjung RHR, Suwito S, Maury HK, Alianto A, Study of Sea Water Quality and Pollution Index Based on Physical and Chemical Parameters in Depapre District Waters, Jayapura, 16:35 (2018)

17. Agustiningsih D, Sasongko SB, Analysis of Water Quality and Water Pollution Control Strategies in Blukar River, Kendal Regency, 9:64-71(2012)

18. Sujati AB, Priyono A, Siti Badriyah D, Water Quality Characteristic of Ciliwung River at Bogor Botanical Garden Segmen, Bogor, Media Konserv Agustus 22:111-117 (2017) 